\title{
The potential for selective pharmacological therapies through biased receptor signaling
}

Terry Kenakin

\begin{abstract}
The discovery that not all agonists uniformly activate cellular signaling pathways (biased signaling) has greatly changed the drug discovery process for agonists and the strategy for treatment of disease with agonists. Technological advances have enabled complex receptor behaviors to be viewed independently and through these assays, the bias for an agonist can be quantified. It is predicted that therapeutic phenotypes will be linked, through translational studies, to quantified scales of bias to guide medicinal chemists in the drug discovery process.
\end{abstract}

\section{Introduction}

Agonists constitute a major class of therapeutic drug and pose special problems with respect to the drug discovery process. Specifically, agonist activity is intimately tied to the sensitivity of the tissue in which the activity is measured therefore the obvious measures of agonist activity (i.e. potency and maximal response) can be complex and certainly are system dependent. As in most cases, new therapeutic entities are discovered, optimized and characterized in test systems, rarely the therapeutic one. Therefore, system-independent reliable scales to describe agonist activity are critical in the process of identifying agonist drug candidates. A pharmacologic workhorse for the quantification of agonist activity has been the agonist potency ratio. This tool compares equal responses via null methods to cancel tissue effects to yield ratios that depend only on agonist affinity and efficacy. Since these are unique properties of the molecules, these ratios can be system independent and invaluable as predictors of activity in therapeutic systems. Potency ratios are applicable only when comparing full agonists and cannot be applied to comparisons of full to partial agonist activity. However, other techniques that identify system independent measures of agonist activity can be estimated through tools such as the Black/Leff operational model; this characterizes the affinity (as $\mathrm{K}_{\mathrm{A}}^{-1}$ where $\mathrm{K}_{\mathrm{A}}$ is the equilibrium dissociation constant of the

\footnotetext{
Correspondence: kenakin@email.unc.edu

Department of Pharmacology, University of North Carolina School of Medicine, 120 Mason Farm Road, Room 4042 Genetic Medicine Building, CB\# 7365, Chapel Hill, NC 27599-7365, USA
}

agonist-receptor complex) and $\tau$ (where $\tau$ is the agonist intrinsic efficacy and sensitivity to agonist of the tissuevide infra) [1]. Thus estimates of $\tau$ and $\mathrm{K}_{\mathrm{A}}$ become the system independent measures of agonism.

The use of these techniques to compare whole cell activity for drug discovery depends on an important assumption, namely that the function linking receptor occupancy and tissue response be monotonic (i.e. that there be only one value of $y$ (response) for every $x$ (concentration of drug)). Under these circumstances, ratios of activity seen for whole cell response should accurately mirror ratios of the initial stimulus that the agonist gives to the system (the molecular properties of affinity and efficacy). A further basic assumption in the use of whole cell relative activities of agonism is that all agonists stabilize a common active state of the receptor to generate response. In the absence of evidence to the contrary, this is the most parsimonious model of agonism and it has been operative for 50 years in pharmacology. However, over the past 20 years there have been a number of papers published that suggest that stimulus-response coupling is more complex [2-9] and that whole cell potency ratios for agonists can be variable. The basis for these ideas stem from examples where multiple responses are measured from a single receptor type showing that some agonists produce pleiotropic responses and others do not. As a preface to the discussion of the mechanism by which this can occur at the receptor level, it is useful to consider a subset of these examples where agonists demonstrate apparently selective pathway agonism because of the efficiency of stimulus-coupling in the cell.

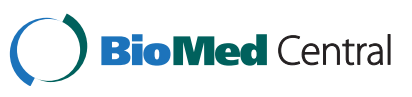

(c) 2012 Kenakin; licensee BioMed Central Ltd. This is an Open Access article distributed under the terms of the Creative Commons Attribution License (http://creativecommons.org/licenses/by/2.0), which permits unrestricted use, distribution, and reproduction in any medium, provided the original work is properly cited. 


\section{Cell system bias}

The efficiency of coupling of various cellular pathways is probably tailored to the needs of the cell. For example, $\beta$ adrenoceptor activation in the rat atrium produces myocardial inotropy (increase force of isometric contraction) and lusitropy (increased rate of relaxation) and it can be seen that dose-response curves for lusitropic effects are shifted by a factor of three to the left of those for inotropic effects [10]-see Figure 1. This would be consistent with a condition whereby lusitropy requires a lower level of cyclic AMP elevation than does inotropy. The relevant point to this discussion is that this cellular bias with respect to signaling is a property of the tissue (not any specific difference in the efficacy of the agonists) and thus it is a condition that will be true for all agonists in the tissue; these effects will be referred to as 'system bias'. Differences in the sensitivity of pathways becomes even more pronounced when different assays are compared. For example, it is generally true that enzyme complementation assays for $\beta$-arrestin effects are considerably less sensitive than second messenger assays such as cyclic AMP elevation. This can lead to a number of apparently 'selective' agonist effects whereby weak agonists can produce activation of only the most efficiently coupled pathway; this effect will be referred to as 'observation bias'. These 'strength of signal' profiles are not necessarily examples of ligand bias and should not be considered as such.

Every pharmacologic experiment concerning agonism will be subject to system and observation bias but these effects can be cancelled through null procedures whereby agonists are compared to each other within a given signaling pathway. In addition, these types of bias generally are not useful therapeutically since all agonists are subject to their effects and the extent of the effect is linked to the nature of the system (i.e. species, organ, experimental conditions etc.). True ligand bias is superimposed upon these effects to produce a ligand-specific agonism that will translate to in vivo systems and give phenotypically unique profiles of agonism.

\section{Ligand directed signaling}

Within the time period where variance of experimental data from theoretical prediction were reported there began to appear cases where a simple strength of signal mechanism could not account for differences in agonist response. It should be noted that the important advancement in pharmacology that allowed these effects to be studied was
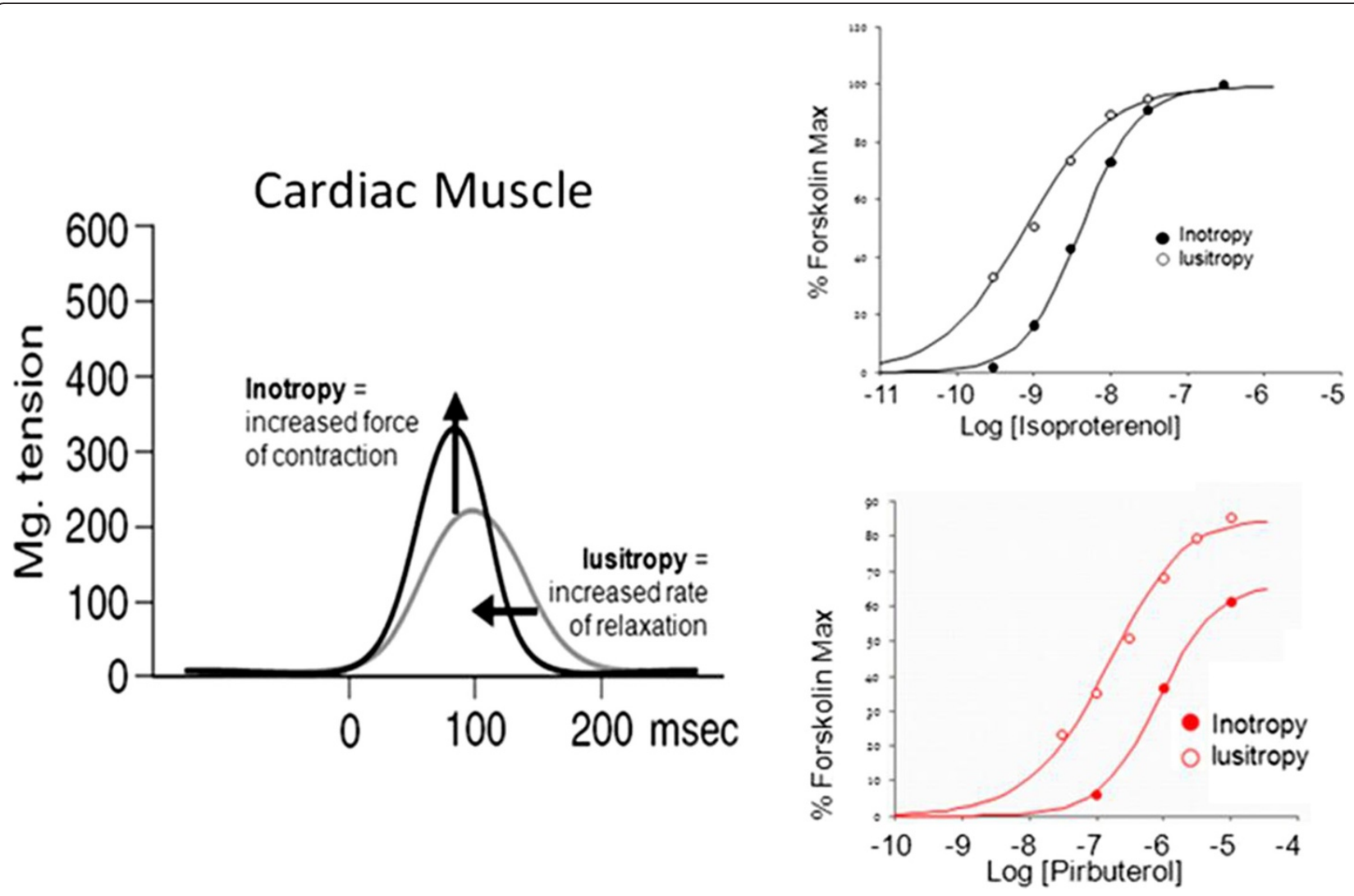

Figure 1 Effects of isoproterenol and pirbuterol on rat atrial isometric contraction peak height (inotropy; filled circles) and rate of relaxation (lusitropy; open circles). The concentration-response curve for lusitropy is shifted 3-fold to the left of the curve for inotropy indicating a difference in the intrinsic coupling efficiencies of the $\beta$-adrenoceptor to these two physiological processes. Data redrawn from [10]. 
(and is) the availability of multiple assays to view receptor behavior. Thus, for example, instead of inferring effects on receptor desensitization and internalization from the disappearance of agonist response, these effects could be viewed independently with imaging assays. When this was done it was seen that internalization did not always parallel agonism and in fact, could be shown to be an independent phenomenon $[11,12]$.

The major type of observation to suggest that agonists possessed the innate property of controlling cellular pathway stimulation is the demonstration that the relative potencies of agonists actually reverse order when two pathways controlled by the same receptor are observed. For example, in LLC-PK1 cells transfected with PACAP receptors the relative potencies of the PACAP analogues PACAP ${ }_{1-27}$ and PACAP ${ }_{1-38}$ for increasing cellular cyclic AMP and inositol phosphate were determined. It was observed that the two agonists reverse their relative order of potency for the two signaling pathways mediated by the same receptor (i.e. the relative potency for cyclic AMP is PACAP $_{1-27}>$ PACAP $_{1-38}$ and $\mathrm{PACAP}_{1-27}<\mathrm{PACAP}_{1-38}$ for inositol phosphate production) [13]. Similarly, the relative potency of Eel and Porcine calcitonin reversed order when HEK cells were enriched with $G_{\alpha s}$ through transduction [14]. In these cases, a strength of signal mechanism cannot account for the difference in potency ratio and another hypothesis is needed.

This type of divergent data for relative agonist potency clearly suggested that the binding of different agonists leads to the production of different receptor species with varying preference for signaling proteins, i.e. different agonists produce different receptor active states; the first proposal of this mechanism labeled the effect 'stimulustrafficking' [15]-see Figure 2. Subsequently, a number of pharmacologic approaches utilizing cellular agonist response were used and data consistent with ligandspecific receptor active state formation were reported (for reviews see [16-20]). Notably, studies with dopamine agonists [3,21] and serotonin [22] clearly showed the effect; the most common terms utilized to describe these effects over this period were agonist 'bias' or 'functional selectivity'. In addition to cellular pharmacologic studies, agonist formation of different receptor states has been shown through chemical and structural studies with a number of techniques (see [23-38]).For example, ${ }^{19} \mathrm{~F}$-NMR studies show the adoption of different $\beta_{2}$-adrenoceptor conformations with binding of different ligands [39]. Therefore, in addition to system bias for any two pathways in the cell (or any two functional response readouts) a ligand bias can be imposed.

\section{How signaling bias alters ligand pharmacology}

True ligand bias denotes that the chemical structure of the molecule has coded within it the information needed to route stimulus to selected signaling proteins in the

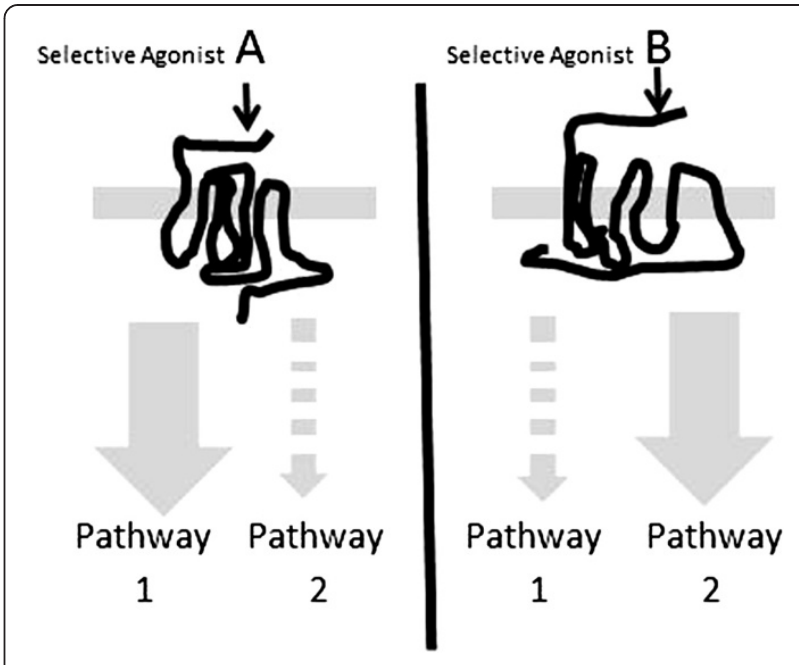

Figure 2 Molecular mechanism for agonist-directed biased signaling. Agonist A stabilizes a conformation of the receptor that preferably activates pathway 1 while agonist B stabilizes a receptor conformation that preferably activates pathway 2 .

cell; this is done through the stabilization of a unique receptor conformations. When controlled through medicinal chemistry, this phenomenon has the potential to improve the signaling profiles of agonists and antagonists for therapeutic benefit. The key to achieving this type of control is to have assays that can detect and quantify selective pathway signaling. For example, in vitro assays that measure second messenger production (eg. cyclic AMP from $G_{\alpha s}$ activation of adenylate cyclase) and the association of receptor with $\beta$-arrestin (Bioluminescent Resonance Energy Transfer, BRET) can be used to separately assess the ability of a ligand to activate the pathways. The other requirement is a quantitative scale by which pharmacologists and medicinal chemists can gauge the effect of changing molecular structure on the bias of a given chemical scaffold. The key to such a scale is that it be intimately associated with the specific pathway being assessed, i.e. as discussed previously, parameters that characterize the receptor species interacting with the signaling molecules must be determined. As a preface to the discussion of system independent parameters of agonism, it is useful to describe the theoretical context of the model for agonism, namely the Black/Leff operational model [1]. In this model, response is controlled by the affinity of the agonist (denoted as $\mathrm{K}_{\mathrm{A}}^{-1}$ where $\mathrm{K}_{\mathrm{A}}$ is the equilibrium dissociation constant of the agonist-receptor complex) and efficacy denoted by $\tau$ where $\tau=\left[R_{t}\right]$ (membrane receptor density) divided by $K_{E}$, the virtual Michaelis-Menten constant for the interaction of the agonist-bound receptor as it interacts with the cell where the cell is defined as a virtual enzyme. The efficacy term $\tau$ thus describes both the 
intrinsic efficacy of the agonist (i.e. the power of the molecule to induce response) and the sensitivity of the system to return response (number of responding units [receptors] and the efficiency of receptor coupling to stimulus-response mechanisms in the cell). Response is thus given by the equation:

$$
\text { Response }=\frac{[\mathrm{A}]^{\mathrm{n}} \tau^{\mathrm{n}} \mathrm{E}_{\mathrm{m}}}{[\mathrm{A}]^{\mathrm{n}} \tau^{\mathrm{n}}+\left([\mathrm{A}]+\mathrm{K}_{\mathrm{A}}\right)^{\mathrm{n}}}
$$

where $\mathrm{n}$ is the Hill coefficient for the agonist concentration-response curve. Since receptors are allosteric proteins, these parameters must involve the constants that define the interactions of the agonist (termed the allosteric modulator of the effect) and the guest (in this case the signaling molecule) with the receptor. The former parameter is the affinity of the agonist for the receptor $\left(\mathrm{K}_{\mathrm{A}}\right)$ which, for allosteric proteins such as receptors, is a conditional parameter. Affinity must be included in the parameter estimate since allosteric mechanisms dictate that $\mathrm{K}_{\mathrm{A}}$ will be different for the agonist-receptor pair for different signaling molecules. This has been shown in structural and binding studies for $\beta_{2}$-adrenoceptors [40], $\mathrm{k}$-opioid receptors [41], and ghrelin receptors [42]. The parameter $\tau$ is a characteristic 'efficacy' of the resulting agonist-receptor complex. Therefore the minimal theoretically sound unit to denote agonist power to produce activation of any given cellular pathway is $\tau / K_{\mathrm{A}}$ (generally utilized as the $\log$ normal parameter $\left.\log \left(\tau / K_{A}\right)\right)$. While this parameter can be estimated by fitting data to equation 1 , it also can be shown that for systems where $n=1, \log \left(\tau / K_{A}\right)$ values reduce to $\log (\mathrm{RA})$ values where RA refers to 'Receptor Activity' indices defined by Ehlert and colleagues [43] as (maximal response)/ $\mathrm{EC}_{50}$ for agonism (where $\mathrm{EC}_{50}$ is the molar concentration producing $50 \%$ maximal response to the agonist). Log (RA) values are the most simple index of agonism and take into account both the sensitivity of the system and the intrinsic efficacy of the agonist. Therefore, the relative $\log \left(\tau / K_{A}\right)$ (or for $n=1$ cases $\log (\mathrm{RA})$ ) values can be evaluated for a series of agonists in a given pathway to rank the relative intrinsic efficacy of the agonists for that pathway. Comparison to the same reference agonist (usually the natural endogenous agonist) for different pathways can then be used to compare the relative power of the agonists to activate different pathways [44]. Theoretically, providing the $\log \left(\tau / K_{\mathrm{A}}\right)$ values represent direct measurement of modulator (agonist)-conduit (receptor)-guest (signaling pathway complexes, they will be system independent measures of agonism [16,44]. Of course where response is measured from points beyond this complex (i.e. where the cell mixes and matches components of response), even Log $\left(\tau / K_{A}\right)$ values become system dependent and less useful as measures of agonist bias.

\section{Therapeutic implications of biased signaling}

The realization that the signaling profiles of agonists may be subject to modification has led to an explosion of proposals in the literature for improved agonists (and antagonists). These are based on data to show that some but not all signaling produced by agonists is beneficial to the host organ. For instance, opioids are valuable analgesics but also can produce respiratory depression. Insofar as respiratory depression can be linked to activation of $\beta$-arrestin [45]), an opioid agonist that stimulates opioid pathways without promoting receptor $/ \beta$-arrestin interaction would be predicted to be a superior therapy [46-48]. Treatment with synthetic orthosteric agonists also precludes receptor occupancy by the endogenous agonist and this becomes an important aspect of the in vivo profile of biased ligands. For instance, in heart failure, blockade of angiotensin receptors precludes damaging angiotensin-mediated vasoconstriction. Treatment with a biased angiotensin antagonist such as TRV120027; Sar-Arg-Val-Tyr-IleHis-Pro-D-Ala-OH blocks angiotensin but also promotes beneficial effects of $\beta$-arrestin activation (stimulation of p42/44 mitogen-activated protein kinase, Src, and endothelial nitric-oxide synthase phosphorylation ) and it is predicted that this will lead to a therapeutic advantage [49-53]. Initial data support this conclusion. In rats, blockade of endogenous angiotensin with conventional angiotensin receptor antagonists losartan and telmisartan, leads to reduced mean arterial pressure but also a decrease in cardiac performance. In contrast, treatment with TRV120027 does not decrease but rather increases cardiac performance and preserves cardiac stroke volume [54]. Similarly, in canine heart failure models TRV120027 produces cardiac unloading actions but preserves renal function resulting in a predicted novel strategy for the treatment of heart failure [55]. It should be noted that while stabilization of receptor conformation is the most commonly proposed mechanism for biased ligand effects, there are potentially other mechanisms that may be operative, especially with respect to peptide ligands such as TRV120027. For example, it has been shown that differential dissociation of the peptides RANTES and AOPRANTES from internalized CCR5 receptors causes differences in the recycling of receptors back to the cell surface upon internalization. Specifically, the lack of dissociation of AOP-RANTES from the receptor in the acidic cytoplasmic environment leads to selective CCR5 endosomal destruction as compared to rapid recycling with RANTES [56]. In general, biased signaling has been proposed to be potentially useful in a host of diseases including hyperlipidemia (GPR109 receptors $[57,58]$ ), heart failure ( $\beta$-adrenoceptors [59-61]), some neuropsychiatric/ 


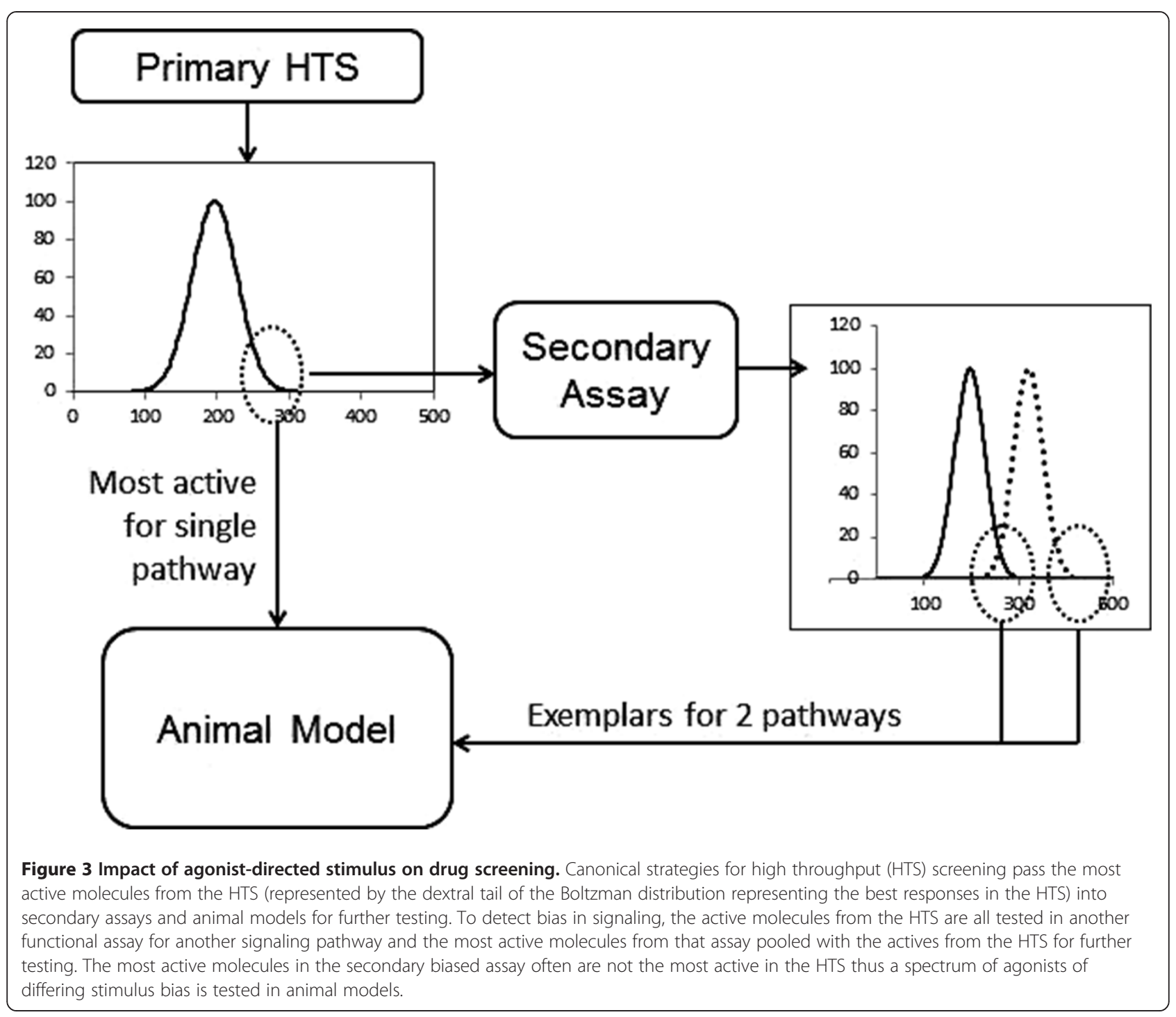

neurodegenerative disorders (histamine $\mathrm{H}_{1}$ receptors [62]), hypertension ( $\alpha_{2}$-adrenoceptors [63]), hypothyroidism (TSR [64]),schizophrenia (dopamine $\mathrm{D}_{2}$ receptors [65-67]), small-cell lung cancer (GRPR/vasopressin [68]), osteoporosis (PTH receptors [69-71]), parkinsonism (dopamine D1 receptors [72]), diabetes (GLP-1 receptors [73]), addiction, psychosis and depression (5-HT receptors [74,75]).

The consideration of biased signaling in various therapeutic areas has been introduced into pharmacology through various means including theoretical predictions based on known signaling components of cells and from studies in gene knockout animals (eg. knockout animals for $\beta$-arrestin-1 [73], $\beta$-arrestin-2 [45], p90 ribosomal S6 kinase [76]). However, there are numerous instances where it still is not yet possible to predict which type of signaling bias may represent a superior therapy. In these cases, empirical testing of exemplar molecules in animal models is a way forward; these approaches have generally led to a revolution in the strategy for new drug discovery.

\section{The impact of signaling bias on drug discovery}

When it was assumed that new synthetic ligands mimic natural endogenous agonists in their quality of efficacy (the pathways they activated in the cell) and only differed in the quantity of efficacy they possessed, a single robust high throughput screen (HTS) with a suitably sensitive readout of cellular response was theoretically adequate to find agonists. The discovery that this is not the case and that some agonists activate selected pathways more than others destroys this assumption. Specifically, a biased agonist may have weak activity in one assay tailored to measure a given pathway but a much stronger activity for 
another pathway not measured by the screening assay. This compels the testing of agonists in multiple pathways, an idea at odds with the obvious resource constraints of discovery efforts. A fruitful compromise may be to test the discovered active molecules from an HTS in other assays designed to measure another pathway. The testing of screening actives in another pathway assay would allow the detection of texture in agonism, i.e. extremes in stimulation profiles could then be taken into animal models to possibly detect unique phenotypes in these models-see Figure 3.

The idea that agonists may bias the stimulus they give to cells is relatively new and as such, may be thought to be somewhat rare. However, an alternative view which considers that receptors can form numerous states (some active with respect to signaling) and that ligands interact with an 'ensemble' of different conformations, predicts a vast array of bias for different agonists [77-82]. Therefore the agonist-stabilized ensemble is the result of an array of conformations stabilized through binding governed by the affinities of the agonist for particular conformations. This idea suggests that it would be unlikely that any two agonists would have identical bias with respect to an array of signaling molecules. Under these circumstances, the high probability that ligands will not have identical affinities for a large number of conformations predicts that ligands will in essence stabilize a nearly unique conformational ensemble and this, in turn, would go on to activate a nearly unique cadre of stimulus cascades in the cell.

\section{Conclusions}

The idea that new agonists may well produce receptor conformations that activate signaling proteins in a biased manner forces pharmacologists to rethink their concepts of agonism, i.e. the most potent and efficacious agonist may not be the best option for therapy. These ideas have extended the field of target validation beyond target type to which signaling pathway mediated by that target type is the relevant 'target' for therapy. It will be most interesting to see if phenotypic signaling determined from in vitro assays translates to unique therapeutic phenotypes in vivo. The various discovery efforts with biased ligands presently in progress should provide answers to this question within the next few years.

\section{Competing interests}

The authors declare that they have no competing interests.

\section{Acknowledgements}

I wish to thank many scientists for helpful discussion on signalling bias including Dr. Bryan Roth, Arthur Christopoulos, Marc Caron, Bill Clarke and Louis Luttrel.

\section{Author contribution}

TPK wrote the article.
Received: 21 June 2012 Accepted: 13 August 2012

Published: 13 August 2012

\section{References}

1. Black JW, Leff P: Operational models of pharmacological agonist. Proc $R$ Soc Lond [Biol] 1983, 220:141-16. 2.

2. Roth BL, Chuang D-M: Multiple mechanisms of serotonergic signal transduction. Life Sci 1987, 41:1051-1064.

3. Mailman RB, Lawler CP, Lewis MM, Blake B: Functional effects of novel dopamine ligands: Dihydrexidine and Parkinson's disease as a first step In Dopamine Receptor Subtypes: From Basic Science to Clinical Application. Edited by Jenner P, Demirdamar R. New York: IOS Press; 1998:53-65.

4. Roerig SC, Loh HH, Law PY: Identification of three separate guanine nucleotide- binding proteins that interact with the $\delta$-opioid receptor in NG108-15 X glioma hybrid cells. Mol Pharmacol 1992, 41:822.831.

5. Fisher A, Heldman E, Gurwitz D, Haring R, Barak D, Meshulam H, Marciano D, Brandeis R, Pittel Z, Segal M, et al: Selective signaling via unique M1 muscarinic agonists. Ann N Y Acad Sci 1993, 695:300-303.

6. Gurwitz D, Haring R, Heldman E, Fraser CM, Manor D, Fisher A: Discrete activation of transduction pathways associated with acetylcholine M1 receptor by several muscarinic ligands. Eur J Pharmacol 1994, 267:21-31.

7. Ward JS, Merrit L, Calligaro DO, Bymaster FP, Shannon HE, Sawyer BD, Mitch CH, Deeter JB, Peters SC, Sheardown MJ: Functionally selective M1 muscarinic agonists. 3. Side chains and azacycles contributing to functional muscarinic selectivity among pyrazacycles. J Med Chem 1995, 38:3469-3481.

8. Heldman E, Barg J, Fisher A, Levy R, Pittel Z, Zimlichman R, Kushnir M, Vogel Z: Pharmacological basis for functional selectivity of partial muscarinic receptor agonists. Eur J Pharmacol 1996, 297:283-291.

9. Lawler CP, Prioleua C, Lewis MM, Mak C, Jiang D, Schetz JA, Gonzalez AM, Sibley DR, Mailman RB: Interactions of the Novel Antipsychotic Aripiprazole (OPC-14597) with Dopamine and Serotonin Receptor Subtypes. Neuro psychopharmacology 1999, 20:612-627.

10. Kenakin TP, Ambrose JR, Irving PE: The relative efficiency of -adrenoceptor coupling to myocardial inotropy and diastolic relaxation: Organ selective treatment for diastolic dysfunction. J Pharmacol Exp Ther 1991 257:1189-1197.

11. Roettger BF, Ghanekar D, Rao R, Toledo C, Yingling J, Pinon D, Miller LJ: Antagonist-stimulated internalization of the $\mathrm{G}$ protein-coupled cholecystokinin receptor. Mol Pharmacol 1997, 51:357-362.

12. Gray JA, Roth BL: Paradoxical trafficking and regulation of $5-\mathrm{HT}(2 \mathrm{~A})$ receptors by agonists and antagonists. Brain Res Bull 2001, 56:441-451.

13. Spengler D, Waeber C, Pantaloni C, Holsboer F, Bockaert J, Seeburgt PH, Journot $L$ : Differential signal transduction by five splice variants of the PACAP receptor. Nature (London) 1993, 365:170-175.

14. Watson C, Chen G, Irving PE, Way J, Chen W-J, Kenakin TP: The use of stimulus-biased assay systems to detect agonist-specific receptor active states: Implications for the trafficking of receptor stimulus by agonists. Mol Pharmacol 2000, 58:1230-1238.

15. Kenakin TP: Agonist-receptor efficacy II: Agonist-trafficking of receptor signals. Trends Pharmacolsci 1995, 16:232-38.

16. Kenakin TP, Miller $L$ : Seven transmembrane receptors as shape shifting proteins: The impact of allosteric modulation and functional selectivity on new drug discovery. Pharmacol Rev 2010, 62:265-304.

17. Perez DM, Karnick SS: Multiple signaling states of G-protein coupled receptors. Pharmacol Rev 2005, 57:147-61.

18. Mailman RB: GPCR functional selectivity has therapeutic impact. Trends Pharmacol Sci 2007, 28:390-396.

19. Leach K, Sexton PM, Christopoulos A: Allosteric GPCR Modulators: Taking Advantage of Permissive Receptor Pharmacology. Trends PharmacolSci 2007, 28:382-389.

20. Kenakin TP: Functional selectivity and biased receptor signaling. J Pharmacol Exp Ther 2011, 336:296-302.

21. Mottola DM, Kilts JD, Lewis MM, Connery HS, Walker QD, Jones SR, Booth RG, Hyslop DK, Piercey M, Wightman RM, et al: Functional selectivity of dopamine receptor agonists. I. Selective activation of postsynaptic dopamine D-1 receptors linked to adenylatecyclase. J Pharmacol Exp Ther 2002, 301:1166-1178.

22. Berg KA, Maayani S, Goldfarb J, Scaramelli C, Leff P, Clarke WP: Effect pathway-dependent relative efficacy at serotonin type $2 \mathrm{~A}$ and $2 \mathrm{C}$ 
receptors: evidence for agonist-directed trafficking of receptor stimulus. Mol Pharmacol 1998, 54:94-104.

23. Baneres J-L, Mesnier D, Martin A, Joubert L, Dumuis A, Bockaret J: Molecular characterization of a purified 5-HT4 receptor. J Biol Chem 2005, 280:20253-20260.

24. Galandrin S, Oligny-Longpre G, Bonin H, Ogawa K, Gales C, Bouvier M: Conformational rearrangements and signaling cascades invovled in ligand-based mitogen-activated protein kinase signaling through the B1-adrenergic receptor. Mol Pharmacol 2008, 74:162-172.

25. Georgieva T, Devanathan S, Stropova D, Park PK, Salamon Z, Tollin G, Hruby VJ, Roeske WR, Yamamura HI, Varga E: Unique agonist-bound cannabinoid CB1 receptor conformations indicate agonist specificity in signaling. Eur J Pharmacol 2008, 581:19-29.

26. Gether U, Lin S, Kobilka BK: Fluorescent labeling of purified $\beta 2$-adrenergic receptor: evidence for ligand specific conformational changes. J Biol Chem 1995, 270:28268-28275.

27. Ghanouni P, Gryczynski Z, Steenhuis JJ, Lee TW, Farrens DL, Lakowicz JR, Kobilka BK: Functionally different agonists produce distinct conformations in G-protein coupling domains of the $\beta 2$-adrenergic receptor. J Biol Chem 2001, 276:24433-24436.

28. Granier S, Kim T, Shafer AM, Ratnala VR, Fung JJ, Zare RN, Kobilka B: Structure and conformational changes in the C-terminal domain of the beta2-adrenoceptor: insights from fluorescence resonance energy transfer studies. J Biol Chem 2007, 282:13895-13905.

29. Hruby VJ, Tollin G: Plasmon-waveguide resonance (PWR) spectroscopy for directly viewing rates of GPCR/G-protein interactions and quantifying affinities. Curr OpinPharmacol 2007, 7:507-514

30. Kobilka B, Gether U: Use of fluorescence spectroscopy to study conformational changes in the beta-adrenoceptor. Methods Enzymol 2002, 343:170-182

31. Lohse MJ, Hein P, Hoffmann C, Nikolaev VO, Viladarga J-P, Bunemann M: Kinetics of G-protein-coupled receptor signals in intact cells. $\mathrm{Br} J$ Pharmacol 2008, 153:S125-S132.

32. Okada T, Palczewski K: Crystal structure of rhodopsin: Implications for vision and beyond. Curr Opin Struc Biol 2001, 11:420-426.

33. Swaminath G, Xiang Y, Lee TW, Steenhuis J, Parnot C, Kobilka BK: Sequential Binding of Agonists to the $\beta 2$ Adrenoceptor: Kinetic evidence for intermediate conformational states. J Biol Chem 2004, 279:686-691.

34. Swaminath G, Deupi X, Lee TW, Zhu W, Thian FS, et al: Probing the $\beta 2$ adrenoceptor binding site with catechol reveals differences in binding and activation by agonists and partial agonists. J Bio Chem 2005, 280:22165-22171.

35. Tutor A, Penela P, Mayor F: Anti- $\beta 1$-adrenergic receptor autoantibodies are potent stimulators of the ERK1/2 pathway in cardiac cells. Cardiovasc Res 2007, 76:51-60.

36. Vilardaga JP, Bunemann M, Krasel C, Castro M, Lohse MJ: Measurement of the millisecond activation switch of G-protein-coupled receptors in living cells. Nat Biotechnol 2003, 21:807-812

37. Viladarga JP, Steinmeyer R, Harms GS, Lohse MJ: Molecular basis of inverse agonism in a G-protein coupled receptor. Nat Chem Biol 2005, 1:25-28.

38. Zurn A, Zabel U, Viladarga JP, Schindlein H, Lohse MJ, Hoffmann C: Fluorescence resonance energy transfer analysis of a2a-adrenergic receptor activation reveals distinct agonist-specific conformational changes. Mol Pharmacol 2009, 75:534-541.

39. Liu JJ, Horst R, Katritch V, Stevens RC, Wuthrich K: Biased signaling pathways in $\beta_{2}$-adrenergic receptor characterized by ${ }^{19} \mathrm{~F}-\mathrm{NMR}$. Science 2012, 335:1106-1110.

40. Rasmussen SGF, DeVree BT, Zou Y, Kruse AC, Chung KY, Kobilka TS, Thian FS, Chae PS, Pardon E, Calinski D, et al: Crystal structure of the 2 adrenergic receptor-Gs protein complex. Nature 2011, 477:549-557.

41. Yan F, Mosier PD, Westkaemper RB, Roth BL: Ga-subunits differentially alter the conformation and agonist affinity of k-opioid receptors. Biochem 2008, 47:1567-1578.

42. Mary S, Damian M, Louet M, Floquet N, Fehrentz J-A, Marie J, Martinez J, Baneres J-L: Ligands and signaling proteins govern the conformational landscape explored by G protein-coupled receptor. Proc Natl Acad Sci USA 2012, /pnas1119881109.

43. Figueroa KW, Griffin MT, Ehlert FJ: Selectivity of agonists for the active state of M1 to M4 muscarinic receptor subtypes. J Pharmacol Exp Ther 2009, 328:331-342
44. Kenakin TP, Watson C, Muniz-Medina V, Christopoulos, Novick S: A simple method for quantifying functional selectivity and agonist bias. ACS Chem Neurosci 2012, 3:193-203.

45. Raehal KM, Walker JKL, Bohn LM: Morphine side effects in $\beta$-arrestin 2 knockout mice. J Pharmacol Exp Ther 2005, 314:1195-1201.

46. Bohn L, Lefkowitz RJ, Gainetdinov RR, Peppel K, Caron MG, Lin F-T: Enhanced morphine analgesia in mice lacking beta-arrestin 2. Science 1999, 286:2495-2498.

47. Xu H, Partilla JS, Wang X, Rutherford JM, Tidgewell K, Prisinzano TE, Bohn LM, Rothman RB: A comparison of noninternalizing (herkinorin) and internalizing (DAMGO) $\mu$-opioid agonists on cellular markers related to opioid tolerance and dependence. SYNAPSE 2007, 61:166.175.

48. Groer CE, Tidgewell K, Moyer RA, Harding WW, Rothman RB, Prisinzano TE, Bohn LM: An opioid agonist that does not induce mu opioid receptorarrestin interactions or receptor internalization. Mol Pharmacol 2007, 71:549-557.

49. Wei H, Ahn S, Shenoy SK, Karnik SS, Hunyady L, Luttrell LM, Lefkowitz RJ: Independent beta-arrestin 2 and $G$ protein mediated pathways for angiotensin II activation of extracellular signal-regulated kinases 1 and 2 . Proc Natl Acad Sci USA 2003, 100:10782-10787.

50. Rajagopal K, Whalen EJ, Violin JD, Stiber JA, Rosenberg PB, Premont RT, Coffman TM, Rockman HA, Lefkowitz RJ: $\beta$-arrestin-2 mediated inotropic effects of the angiotensin II type $1 \mathrm{~A}$ receptor in isolated cardiac myocytes. Proc Natl Acad Sci USA 2006, 103:16284-16289.

51. Aplin M, Bonde MM, Hansen JL: Molecular determinants of angiotensin II type 1 receptor functional selectivity. J Mol Cell Cardiol 2009, 46:15-24.

52. Violin JD, Lekowitz RJ: $\beta$-arrestin-biased ligands at seven transmembrane receptors. Trends Pharmacol Sci 2007, 28:416-422.

53. Zhai P, Yamamoto M, Galeotti J, Liu J, Masurekar M, Thaisz J, Irie K, Holle H, Yu X, Kupershmid S, et al: Cardiac-specific overexpression of At1 receptor mutant lacking Gaq/Gai coupling causes hypertrophy and bradycardia in transgenic mice. J Clin Invest 2005, 115:3045-3056.

54. Violin JD, DeWire SM, Yamashita D, Rominger DH, Nguyen L, Schiller $K$, Whalen EJ, Gowen M, Lark MW: Selectively engaging $\beta$-arrestins at the angiotensin II type 1 receptor reduces blood pressure and increases cardiac performance. J Pharmacol, Exp Ther 2010, 335:572-579.

55. Boerrigter G, Lark MW, Whalen EJ, Soergel DG, Violin JD, Burnett JC: Cardiorenal actions of TRV120027, a novel $\beta$-arrestin-biased ligand at the angiotensin II type 1 receptor, in healthy and heart failure canines: a novel therapeutic strategy for acute heart failure. Circ Heart Fail 2011, 4:770-778.

56. Mack M, Luckow B, Nelson PJ, Cihack J, Simmons G, Clapham PR, Signoret N, Marsh M, Stangassinger M, Borlat F, et al: Aminooxypetnane-RANTES induces CCR5 internalization but inhibits recycling: a novel inhibitory mechanism mechanism for HIV infectivity. J Exp Med 1998, 187:1215-1224.

57. Walters RW, Shukla A, Kovacs JJ, Violin JD, DeWire SM, Lam CM, Chen JR, Muelbauer MJ, Whalen EJ, Lefkowitz RJ: $\beta$-arrestin 1 mediates nicotinic acid-induced flushing, but not its antilipolytic effect, in mice. J Clin Invest 2009, 119:1312-1321.

58. Richman JG, Kanetemitsu-Parks M, Gaidarov I, Cameron JS, Griffin P, Zheng H, Guerra NC, Chm L, Maciejewski-Lenoir D, et al: Nicotinic acid receptor agonists differentially activate downstream effectors. J Biol Chem 2008, 283:6232-6240.

59. Shizukuda $Y$, Buttrick PM: Subtype specific roles of $\beta$-adrenergic receptors in apoptosis of adult rat ventricular myocytes. J Mol Cell Cardiol 2002, 34:823-831.

60. Metra M, Dei Cas L, di Lenarda A, Poole-Wilson P: Beta-Blockers in Heart Failure: Are Pharmacological Differences Clinically Important? Heart fail. Rev 2004, 9:123-130.

61. Wisler JW, DeWire SM, Whalen EJ, Violin JD, Drake MT, Shenoy SK, Lefkowitz RJ: A unique mechanism of $\beta$-blocker action: Carvedilol stimulates $\beta$-arrestin signaling. Proc Natl Acad Sci USA 2007, 104:16657-16662.

62. Galeotti N, Malmberg-Aiello P, Bartolini A, Schunack W, Ghelardini C: $\mathrm{H} 1$-receptor stimulation induces hyperalgesia through activation of the phospholipase C-PKC pathway. Neuropharmacol 2004, 47:295-303.

63. Schmid CL, Raehal KM, Bohn LM: Agonist-directed signaling of the serotonin $2 \mathrm{~A}$ receptor depends on $\beta$-arrestin- 2 interactions in vivo. Proc Natl Acad Sci USA 2008, 105:1079-1084.

64. Vassart G, Dumont JE: The thyrotropin receptor and the regulation of thyrocyte function and growth Endocr. Rev 1992, 13:596-611. 
65. Mailman RB: GPCR functional selectivity has therapeutic impact. Trends Pharmacol Sci 2007, 28:390-396.

66. Grady MA, Gasperoni TL, Kirkpatrick P: Aripiprazole. Nat Rev Drug Disc 2003, 2:427-428.

67. Urban JD, Vargas GA, von Zastrow M, Mailman RB: Aripirazole has functionally selective action at dopamine D2 receptor-mediated signaling pathways. Neuropsychopharmacol 2007, 32:67-77.

68. MacKinnon AC, Tufail-Hanif U, Lucas CD, Jodrell D, Haslett C, Sethi T: Expression of V1A and GRP receptors leads to cellular transformation and increased sensitivity to substance-P analogue-inducedgrowth inhibition. Br J Cancer 2005, 92:522-531.

69. Gesty-Palmer D, Flanner P, Yuan L, Corsino L, Spurney R, Lefkowitz RJ, Luttrell LM: A $\beta$-Arrestin-Biased Agonist of the Parathyroid Hormone Receptor (PTH1R) Promotes Bone Formation Independent of G Protein Activation. Sci Transl 2009, 1:1ra1.

70. Schmid CL, Raehal KM, Bohn LM: Agonist-directed signaling of the serotonin $2 \mathrm{~A}$ receptor depends on $\beta$-arrestin-2 interactions in vivo. Proc Natl Acad Sci USA 2008, 105:1079-1084.

71. Ferrari SL, Pierroz DD, Glatt V, Goddard DS, Bianchi EN, Lin FT, Manen D, Bouxsein ML: Bone response to intermittent parathyroid hormone is altered in mice bull for (beta) arrestin 2. Endocrinol 2005, 146:1854-1862.

72. Ryman-Rasmussen JP, Griffith A, Oloff S, Vaidehi N, Brown JT, Goodard WA, Mailman RB: Functional selectivity of dopamine D1 receptor agonists in regulating the fate of internalized receptors. Neuropharmacol 2007, 52:562-575

73. Sonoda N, Imamura T, Yoshizaki T, Babendure JL, Lu J-C, Olefsky JM: $\beta$-arrestin-1 mediates glucagon-like peptide-1 signaling to insulin secretion in cultured pancreatic $\beta$ cells. Proc Natl Acad Sci USA 2008, 105:6614-6619.

74. Ji S-P, Zhang Y, van Cleemput J, Jiang W, Liao M, Li L, Wan Q, Backstrom JR, Zhang X: Disruption of PTEN coupling with $5-\mathrm{HT} 2 \mathrm{C}$ receptors supporesses behavioral responses induced by drugs of abuse. Nat Med 2006, 12:324-329.

75. Willins DL, Berry SE, Alsayegh L, Backstrom JR, Sanders-Bush E, Friedman L, Roth BL: Clozapine and other 5-HT2A antagonists alter the subcellular distribution of 5-hydroxytryptamine $2 \mathrm{~A}$ receptors in vitro and in vivo. Neuroscience 1999, 91:599-606.

76. Strachan RT, Sciaky N, Cronan MR, Kroeze WK, Roth BL: Genetic deletion of p90 Ribosomal S6 kinase 2 alters patterns of 5-hydroxytryptamine2A serotonin receptor functional selectivity. Mol Pharmacol 2010, 77:327-338.

77. Fraunfelder H, Parak F, Young RD: Conformational substrates in proteins. Annu Rev BiophysBiophysChem 1988, 17:451-79.

78. Fraunfelder $\mathrm{H}$, Sligar SG, Wolynes PG: The energy landscapes and motions of proteins. Science 1991, 254:1598-1603.

79. Woodward C: Is the slow-exchange core the protein folding core? Trends Biochem. Sci 1993, 18:359-60.

80. Hilser J, Freire E: Predicting the equilibrium protein folding pathway: structure-based analysis of staphylococcal nuclease. Protein StructFunctGenet 1997, 27:171-83.

81. Hilser VJ, Garcia-Moreno EB, Oas TG, Kapp G, Whitten ST: A statistical thermodynamic model of protein ensembles. Chem Rev 2006, 106:1545-1558.

82. Kenakin TP: Efficacy at G Protein Coupled Receptors. Annual Review of Pharmacology and Toxicology 2002, 42:349-379.

\section{Submit your next manuscript to BioMed Central and take full advantage of:}

- Convenient online submission

- Thorough peer review

- No space constraints or color figure charges

- Immediate publication on acceptance

- Inclusion in PubMed, CAS, Scopus and Google Scholar

- Research which is freely available for redistribution 